\title{
THE IMPACT ON MARRIAGES OF ADULT-ONSET PARAPLEGIA
}

\author{
By Kathleen Shea Abrams, M.R.C., M.A., Ph.D. \\ Psychology Service, Veterans Administration Medical Center, \\ Miami, Florida, U.S.A.
}

\begin{abstract}
Paraplegia does not seriously impair marital functioning according to a critical review of the English-language literature from the last three decades on the marital impact of adult-onset paraplegia. The review focuses on what is currently known about three aspects of marital functioning in paraplegics: marital stability, sexual interaction and marital satisfaction. The discussion highlights implications for health care personnel who advise or counsel paraplegic patients or their spouses about marital concerns.
\end{abstract}

Key words: Marriage; Divorce; Sex; Companionship; Counselling.

\section{Introduction}

STUDIES of the marital impact of adult-onset paraplegia, and of physical disabilities in general, are a recent phenomenon. Almost all studies reviewed for this paper were published after I960. This paper will examine studies of three types of marital variables, specifically marital stability, sexual interaction and marital satisfaction.

Marital stability refers to the incidence of divorce or separation following disability onset. Sexual interaction refers to changes in sexual pleasure, interest, frequency or performance following onset. Marital satisfaction refers to changes in companionship, communication and discord in the couple's relationship following onset. For the purpose of this paper adult-onset paraplegia means to the onset, after the age of 18 , of spinal-cord injury, polio or other disabilities affecting the spinal cord whose major result is paralysis of lower or upper extremities or both.

\section{Impact on Marital Stability}

Though marriage termination by divorce or separation is one important measure of marital discord, it is important to note that non-termination is not a reliable indicator of marital satisfaction. Troubled marriages in which one member is paraplegic may continue for the same reasons as do other troubled marriageschildren, finances, social pressure and lack of viable alternatives, to name several.

This review of marital termination studies will measure studies against two yardsticks or criteria to determine the soundness of their results. One yardstick is whether the study examined the nature and severity of marital stress that existed prior to disability onset. The second yardstick is whether the study used a comparison group that was comparable to the study group on the basis of age, income or socioeconomic status. Age, income and socioeconomic status are significantly correlated with the probability of marital termination according to Blood's 1972 review of studies of marital termination of people without physical disabilities. 


\section{Analysis of studies}

A recent official publication of the Cleveland, Ohio Veteran's Administration Medical Centre asserts that spinal cord injured patients who were married at the time of injury have a higher divorce rate than does the general population (Eisenberg \& Rustad, I974). The publication is a pamphlet written to inform and advise spinal cord injured patients about marital and sexual matters. A patient might assume from the pamphlet's assertion about higher divorce rates for patients married prior to injury that the onset of the disability was a major factor in the divorce. However, the assertion fails to hold up under careful scrutiny of the study on which it is based. Comarr's 1972 study examined the divorce rates of 858 cord injured veterans and found divorce rates of $\mathrm{I} 7$ per cent for married veterans who were injured after they left military service and 30 per cent of married veterans who were injured while in military service. Therefore, the highest rate is a 30 per cent divorce rate. However, the same study reported that approximately 28 per cent of the 858 patients in the study had been divorced prior to injury. Consequently, the divorce rate for this population after injury is nearly equivalent to the divorce rate before injury. Furthermore, comparing the divorce rate of a spinal cord injured population with that of the general population is inappropriate because the spinal cord injured population tends to be younger and, therefore, would be expected to have a higher divorce rate simply on the basis of youth (Blood, op. cit.).

El Ghatit \& Hanson's 1975 study of the outcomes of 333 American marriages in which the husband was spinal cord injured concluded that the group's divorce rate was comparable to that of the general population of the state. Surprisingly, marriages with children were significantly more likely to end in divorce than marriages without children. Furthermore, families which added children following injury were much more likely to end in divorce than families in which all the children were present prior to injury. If, as Blood's 1972 review concludes, having too little money increases the probability of divorce, then perhaps the more children a couple has, the greater financial stress they have and the greater the chance of divorce. In the case of these spinal cord injured patients, we can only conjecture because El Ghatit \& Hanson's study did not provide financial information about the patients studied. The study did, however, find that marriages where the husband had been continuously employed following injury had the lowest divorce rates. This information about employment, in conjunction with the information about the number of children in the family, suggests that income may indeed be one of the most important factors in marriage termination.

Guttmann's I964 study of more than I000 male and nearly 200 female spinal cord injured patients in Great Britain concluded that their divorce rate was only slightly higher than that of the general British population. Another conclusion was that patients who had been married at the time of injury had a lower divorce rate than patients who married after injury. The study failed to provide the data on which this conclusion is based. If the conclusion is valid, however, then it may be that a person who marries shortly after injury may have difficulty attaining new physical functioning and new marital functioning at the same time. One may have to be established before the person can attain the other with some reasonable chance of success.

Finally, Nagi \& Clark's I964 study of 294 severely disabled post-polio adults found that 58, or 19 per cent, had separated or divorced following their disability. Compared with the still-married subjects, the separated or divorced subjects were 
found to be younger, less educated, poorer and more likely to have lived with their parents after marriage.

Thus, even without the presence of a physical disability, factors such as youth, education, income and parental interference may explain the marital termination. Since this study did not use a measure of marital difficulties existing prior to disability onset, it is difficult to know how the presence of the physical disability affected marital stability.

\section{Conclusion}

Studies of the impact of adult-onset paraplegia on marital stability have resulted in no consistent evidence of increased rates of marital termination following disability onset. The studies provided insufficient information about income, age and other factors important to marital stability. Nonetheless, the data that the studies provided suggest that low income and unemployment may be the most significant predictors of marital termination among paraplegic patients.

\section{Impact on sexual interaction}

Frequency of sexual intercourse is a quantitative measure of sexual interaction. A spouse's global sexual satisfaction report is a qualitative measure. Of the two measurement modes, quantitative measures, especially sexual frequency, are more common in the literature about impact of paraplegia on marital sexual interaction. Not surprisingly, self-report was the assessment method of choice in the literature. Because marital sexual interaction involves both members of the couple, the impact of paraplegia is more adequately assessed by asking both, rather than only one. Also, it is better to ask each member separately and independently, rather than together, in an effort to gather data unaffected by knowledge of the other members' interview responses. Some measure of pre-onset sexual functioning is necessary to assess the effect of the paraplegia on sexual interaction. By necessity, the measure used in the studies reviewed was a retrospective estimate of pre-onset sexual functioning.

\section{Analysis of the studies}

The impact of severe mobility impairment on sexual interaction was investigated in a study of orthopaedically disabled married women (Fink, Skipper \& Hallenbeck, 1969). Spinal cord injuries, post-polio conditions and others characterised the women studied. This noteworthy study compared the degree of mobility impairment with the degree of sexual satisfaction and overall marital satisfaction reported by the women and their husbands. The study found no relationship between severity of mobility impairment and sexual satisfaction, as reported by either the wife or the husband. A statistically significant positive correlation was found between the woman's sexual satisfaction and her overall marital satisfaction. A positive, but statistically nonsignificant, correlation was found between the husband's sexual satisfaction and his overall marital satisfaction. Additionally, a positive, but, again, statistically nonsignificant, correlation was found between a woman's sexual satisfaction and that of her husband. These correlational data illustrated the importance of assessing both members of the couple on measures of sexual functioning.

A study of Berkman, Weissman \& Frielich (1978) of spinal cord injured male veterans found that most of the subjects reported using oral-genital sex as their most frequent form of sexual activity, even though 70 per cent of them reported being able to maintain an erection. Only 25 per cent reported using manual stimulation as their sole form of sexual activity. Seventy-five per cent of the subjects stated that their partners were usually satisfied. Surprisingly, this study 
provided no report of the men's own level of sexual satisfaction. Since their sexual partners were not interviewed, only one side of the story is known and no comparisons between the level of satisfaction of the men and of their partners is possible. Furthermore, interpretation of the impact of the physical disability on the choice of sexual activity is difficult because of lack of assessment of preferred sexual activity prior to disability.

Guttmann's I964 study is important as one of the earliest studies of paraplegic patients' sexual functioning. Unfortunately, the study's conclusions are based primarily on case studies using anecdotal information. The study's primary conclusion about sexual functioning is that, in some cases, the unimpaired wife's sexual frustration may result in divorce. A question of whether the wife's sexual frustration might have existed prior to the husband's disability remains unanswered, because the study lacked any measure of the couple's pre-onset sexual interaction.

\section{Conclusion}

Despite the last decade's burgeoning interest in sexual education for spinal cord injured patients, it is surprising that so few studies of paraplegia's impact on a couple's sexual interaction have been published. Furthermore, no study found in the literature assessed the couple's pre-onset sexual interaction and only one asked the unimpaired member of the couple about sexual functioning. A review of sexual interaction studies of other kinds of physical disabilities, such as end-stage renal disease, myocardial infarction and cancer, suggests that the level of pre-onset sexual activity is the best predictor of the level of post-onset sexual activity for both men and women. This generalisation holds true with different age groups and different disabilities, except in those cases in which the disorder itself, such as prostatic cancer, or the treatment, such as hypertensive medication, directly impairs sexual performance. Until more is known about how adult-onset paraplegia affects a couple's sexual interaction, post-onset sexual satisfaction, interest and frequency are most likely to be predicted by knowing the couple's pre-onset levels of sexual functioning.

\section{Impact on marital satisfaction}

Marital satisfaction is a term that refers to a couple's relationship including how the couple spends time together, how they communicate with each other, and how satisfied they are with their relationship. Few studies have examined marital satisfaction changes after the onset of a physical disability. Nonetheless, widespread and long-lasting changes in marital satisfaction after the occurrence of a disability like paraplegia have been assumed by counsellors and other health care personnel (Bruhn, I977; Parsons \& Fox, 1952). It is important, then, to determine if the studies' findings support this assumption.

\section{Analysis of studies}

In an early report of clinical experiences with adult-onset polio patients, Visotsky, Hamburg, Goss and Lebovits (I96I) found that the patients' return to their homes, after lengthy hospitalisation, was marked by 'a good deal of marital difficulty (followed by) considerable resolution of exceedingly difficult problems' (p. 434). Unfortunately, this study supplied very little supportive data, thus limiting the confidence that can be placed in its conclusions about either the extent of marital conflicts or their eventual resolution.

A later study by Fink, Skipper \& Hallenbeck (1968) found that 'the physical 
condition of the disabled woman is not a useful predictor of . . marital satisfaction in either member of the couple' (p. 64). As mentioned previously, Fink et al. assessed orthopaedically handicapped women and their non-disabled husbands. This study found that the woman's rating of her marital satisfaction was not significantly related to her husband's rating of his own marital satisfaction. This finding illustrates the importance of a researcher, or a counsellor, gathering information from both members of the couple.

Besides examining marital satisfaction as a whole, Fink et al. also examined marital companionship, which the study defined as the amount of time a couple spent together and the number of activities they shared. Not surprisingly, the study found that husbands of women with severe mobility limitations reported spending more time at home with their wives than did the husbands of less impaired women. With reference to shared away-from-home activities, husbands of the more impaired women reported less companionship satisfaction than did other husbands, apparently because of a great decline in a couple's activities outside the home following disability onset. This study concluded that 'the less the disabled woman's physical mobility, the less her husband's companionship satisfaction'. (p. 7I). It is important to remember that this relationship does not hold for overall marital satisfaction, as examined by Fink et al.

\section{Conclusion}

Mobility impairments are likely to affect marital companionship by increasing the amount of time a couple spends together at home, while decreasing the number of shared activities away from home. Non-disabled spouses are likely to report dissatisfaction with this change in the couple's relationship. So few studies have been done on marital satisfaction changes following paraplegia that it is premature to assume that the disability inevitably or usually changes a couple's overall marital satisfaction.

\section{Implications for counsellors}

Any person working with paraplegic patients can provide information, advice or counselling about marital concerns to a patient who requests it. Patients seeking such help often do so under the guise of simply asking questions about other patients; for example, how have other patients managed long hospitalisations which prevented them from being with their spouses? No matter what initial approach patients use, those with marital concerns generally respond to an interested and unhurried listener by disclosing their doubts and anxieties about themselves, their spouses and their marital relationship.

Initially, patients who have had satisfactory marriages and those who have had troubled marriages prior to disability onset may ask similar questions and seek similar kinds of information and counselling. Both will benefit from information and reassurance about sexual functioning. However, patients with alreadytroubled marriages may show signs of increased anxiety or depressed feelings following sexual education, because of his or her marital difficulties. The patients may react by blaming their disability for their marital problems and may even try to delay discharge, complaining that the hospital or centre has not done enough.

\section{Conclusions}

Several of the studies reviewed here tell us not to conclude that a patient's marital difficulties necessarily, or even typically, result from the physical disability. 
The studies suggest that an assessment of the patient's pre-onset marital relationship may often reveal that the same difficulties existed prior to the disability and may simply have been exacerbated by the stress of the physical disability. Referral to a trained marriage counsellor is recommended as part of the total rehabilitation effort for those patients and their spouses who have a history of prior serious or chronic marital stress.

Studies of marital satisfaction suggest that companionship satisfaction suffers when couples no longer can share away-from-home activities. Health care personnel can assist couples to maintain or even to improve their shared activities by teaching them new ways to participate in former activities or by teaching them activities which they hadn't shared before the disability. Swimming, fishing, bird-watching and photography are examples of activities that a paraplegic person and a non-disabled spouse can share, with some instruction and practice.

Health care personnel can help couples enhance their marital relationship by routinely offering them an opportunity to learn and participate in activities like these before the patient is discharged.

Special acknowledgement to Raissa Maurin, Chief of Library Services, Veterans Administration Medical Center, Miami, Florida, for assistance with the French and German translations.

\section{RÉSUMÉ}

On ne doit pas tirer la conclusion par les recherches considérées ici que les difficultés conjugales d'un paraplégique résultent nécessairement, ou même typiquement, d'une invalidité physicale. Les recherches suggérent qu'une évaluation des rapports maritaux du patient révèle souvent que les mêmes difficultés ont existé avant l'invalidité et ont été exacerbées simplement par la tension de l'infirmité physicale. Une consultation avec un conseiller de mariage est recommandé comme part de la rehabilitation totale pour ces paraplégiques et leurs époux qui ont une histoire de tension conjugale.

Des recherches de satisfaction maritale suggérent que la satisfaction de camaraderie suffert quand les couples ne peuvent plus participier ensemble aux activités hors de chez eux. Le personnel médical peut assister aux couples à entretenir ou même à améliorer leurs activités partagées. Il peut leur montrer de nouvelles façons à participier aux activités anciennes ou leur suggérer des divertissements qu'ils n'avaient pas partagés avant l'infirmité. La natation, la pêche, observer des oiseaux, et la photographie sont plusieurs divertissements qu'un paraplégique et son époux valid peuvent partager, avec un peu d'instruction et d'exercise.

Le personnel médical peut aider aux couples à intensifier leurs rapports maritaux en leur présentant l'occasion d'apprendre et de partager telles activités quand le patient est encore à l'hôpital.

\section{ZUSAMMENFASSUNG}

Die Studien die wir hier besprechen, zeigen uns daß man die Körperbeschädigung (Lähmung) nicht als die bestimmende oder typische Ursache der eheligen Schwierigkeiten ansehen soll. Eine Auswertung der eheligen Beziehungen kann häufig offenbaren daß die selben Schwierigkeiten existieren vor dem Beginn der Krankheit und waren lediglich verschlimmert unter dem Druck der körperlichen Beschädigung. For Pazienten und ihre Gattinen die eine Vorgeschichte von Ehe-Schwierigkeiten aufweisen Verweisung zu einem geschulten Eheberater ist empfohlen als Teil eines totalen Rehabilitierungs-Versuchs.

Studien der ehlichen Erfüllung zeigen an daß die Erfüllung des Gemeinschaftsgefühls leidet wenn das Paar nicht mehr die "Außer-dem-Heim" Tätigkeiten miteinander genießen kann. Krankheitsdienst Personal kann den Eheparen helfen ihre gemeinsamen Tätigkeiten aufrecht zu erhalten oder sogar zu verbeßern durch Unterrichtung neuer Wege und Arten diese Tätigkeiten auszuführen oder durch Einführung neuer Tätigkeiten die man gemeinsam unternehmen kann. Schwimmen, angeln, birdern und photographieren sind ein Beispiel der Tätigkeiten die gelähmte und gesunde Personen gemeinsam unternehmen können nach kurzer Einleitung und Übung. 
Krankheitsdienst Personal kann den Eheparen helfen ihre Eheverhältniße zu verstärken durch regelmäßigen Unterricht und Besorgung der Gelegenheiten in solchen Tätigkeiten teilzunehmen ehe der Pazient entlaßen wird.

\section{REFERENCES}

Berkman, A., Weissman, R. \& Frielich, M. (I978). Sexual adjustment of spinal cord injured veterans living in the community. Archives of Physical Medicine $\mathcal{E}$ Rehabilitation, 59 (I), 29-33.

Blood, R. O. (1972). The Family. New York: The Free Press.

BRuHn, J. (1977). Effects of chronic illness on the family. Fournal of Family Practice, 4, I057-1060.

Deutsch, C. P. \& Goldstom, J. A. (1960). Family factors in home adjustment of the severely disabled. Marriage and Family Living, 22, 312-316.

EISENBERG, M. G. \& Rustad, L. C. (1974). Sex and the spinal cord injured: some questions and answers (2nd edition). Washington, D.C.: U.S.A. Government Printing Office.

El Ghatit, A. Z. \& Hanson, R. W. (I975). Outcome of marriages existing at the time of a male's spinal cord injury. Fournal of Chronic Diseases, 28, 383-388.

Fink, S. L., Skipper, J. K. \& Hallenbeck, P. N. (I968). Physical disability and problems in marriage. Fournal of Marriage and the Family, 30 (I), 64-73.

Guttman, L. (1964). The married life of paraplegics and tetraplegics. Paraplegia, 2, I82-I 88.

NAGI, S. Z. \& ClARK, D. L. (1964). Factors in marital adjustment after disability. fournal of marriage and the family, 26 (2), 21 5-216.

Parsons, T. \& Fox, R. (1952). Illness, therapy and the modern urban American family. fournal of Social Issues, 8 (4), 3I-44.

Visotsky, H., Hamburg, D., Goss, M. \& Lebovits, B. (I96I). Coping behavior under extreme stress: observations of patients with severe polio. Archives of General Psychiatry, 5, 424-448. 